\title{
Theorizing the Judicialization of International Relations
}

\author{
Karen J. Alter \\ Northwestern University; iCourts, University of Copenhagen \\ Emilie M. Hafner-Burton \\ University of California San Diego \\ AND \\ Laurence R. Helfer \\ Duke University; iCourts, University of Copenhagen
}

\begin{abstract}
This article introduces a Thematic Section and theorizes the multiple ways that judicializing international relations shifts power away from national executives and legislatures toward litigants, judges, arbitrators, and other nonstate decision-makers. We identify two preconditions for judicialization to occur-(1) delegation to an adjudicatory body charged with applying designated legal rules, and (2) legal rights-claiming by actors who bring-or threaten to bring-a complaint to one or more of these bodies. We classify the adjudicatory bodies that do and do not contribute to judicializing international relations, including but not limited to international courts. We then explain how rights-claiming initiates a process for authoritatively determining past violations of the law, identifying remedies for those violations, and preventing future violations. Because judicializing international relations occurs in multiple phases, in multiple locations, and involves multiple actors as decisionmakers, governments often do not control the timing, nature, or extent to which political and policy decisions are adjudicated. Delegation-and the associated choice of institutional design features-is thus only the first step in a chain of processes that determine how a diverse array of nonstate actors influence politically consequential decisions.
\end{abstract}

International relations (IR) are now experiencing what has become the norm in many domestic systems: the judicialization of politics. International rules have long regulated a range of important topics-how and when war is waged, what barriers to imported goods states can impose, which nation owns islands and rocks in the sea, when and how borders shift, and how governments treat their own citizens. The extent to which these rules can be challenged in court, however, and the diversity of actors that can invoke and influence adjudication processes and outcomes, are novel, wide-ranging, and underspecified both theoretically and empirically.

Judicialization is the process by which courts and judges increasingly dominate politics and policy-making (Tate $1995,28) .{ }^{1}$ At the international level, judicialization-where it exists - can diminish the sovereignty of states and the autonomy of their leaders. Several recent examples illustrate

Karen J. Alter is a professor of political science and law at Northwestern University and permanent visiting professor at iCourts: Center of Excellence for International Courts at the University of Copenhagen.

Emilie M. Hafner-Burton is the John D. and Catherine T. MacArthur Professor of International Justice and Human Rights at the School of Global Policy and Strategy and the Department of Political Science at the University of California San Diego and director of the Laboratory on International Law and Regulation.

Laurence R. Helfer is the Harry R. Chadwick, Sr. Professor of Law at Duke University and codirector of the Duke Center for International and Comparative Law, and a permanent visiting professor at iCourts.

Authors' note: Thanks to the IO Foundation, iCourts, and the Danish National Research Foundation, grant no. DNRF105, for financial support. Thanks to Andrew Day, Jeff Cercucan, and the Buffett Institute at Northwestern University for help in hosting our meetings, to Erik Voeten for his deep engagement, to the GUITARs seminar at Georgetown University for helpful feedback on earlier drafts, and to the participants of our workshops on the judicialization of international relations.

${ }^{1}$ For a discussion of the ways in which politics become judicialized, see Hirschl (2004) and Hudec (1971). this effect around the world. In Latin America, the InterAmerican Court of Human Rights' rejection of amnesties for the perpetrators of human rights violations and atrocities has pushed governments in Argentina, Brazil, Peru, El Salvador, and other countries to prosecute international crimes without destabilizing domestic political bargains (Fortes et al. 2017). China's vociferous opposition to an arbitral ruling rejecting its expansive claims to the South China Sea may suggest that legal bodies can do little when opposed by powerful interests. Yet, commentators have identified a variety of ways in which the ruling may be a "game changer" for negotiations between China and its Southeast Asian neighbors and for international maritime politics more generally (Graham 2016). In the United States, President Trump continues to attack the World Trade Organization (WTO) and North American Free Trade Agreement (NAFTA), both of which include international adjudication mechanisms. The political rhetoric is often extreme, but government advisors have channeled concrete proposals in ways that are more legally defensible, and some proposals-like border value-added taxes-are shelved altogether because they would likely trigger WTO adjudication (Worstall 2017).

These examples-and others explored in this Thematic Section-illustrate how judicialization creates a "profound shift in power away from legislatures [and executives] and toward courts and other legal institutions around the world." (Ferejohn 2002, 41) To be sure, this shift does not mean that officials cannot flout law-whether domestic or international. Rather, where government actions are subject to judicial review, the ability to label an act as a legal violation may mobilize rights-claiming and a turn to courts, producing outcomes that may be quite different from what the absence of judicialized politics would otherwise have engendered. 
While judicialization can, under certain conditions, reduce state control over political processes and outcomes, this result may or may not be normatively desirable. The intervention of judges and arbitrators can foster neutral decision-making, help states to send credible signals, and help to resolve collective problems. Expanding venues for nonstate actors, such as nongovernmental organizations (NGOs), to influence politics can generate a sense of inclusion, fairness, and transparency. Yet, judicialized international relations also have potential vices. Judicialization can lead to politics by other means, privileging well-resourced and law-savvy actors (Galanter 1974). It can thwart policies that have popular support and create legitimacy problems when judges and arbitrators cannot be held accountable for their actions. Under some conditions, judicialization can augment (rather than diminish) state power. And precisely because judicialization limits executive and legislative power and constrains domestic policies, it may contribute to backlashes against international regimes.

Whatever its normative valence, the judicialization of international relations has two institutional preconditions. The first is delegation. Scholars have thus far mainly analyzed the existence and forms of state delegation to international courts or arbitral bodies. We focus instead on the conditions under which adjudicatory institutions can shape real world political and policy decisions, demonstrating that treaty-based delegations are but one way to empower adjudicators and that states alone do not determine the content and scope of delegations.

A second, less studied, precondition for judicializing international relations is legal rights-claiming. One or more actors with standing must bring-or threaten to bring-a complaint to an adjudicatory body. The filing of such suits initiates a process for authoritatively naming legal violations, identifying remedies for those violations, and preventing future violations. We thus show that delegation alone is insufficient to explain whether and how adjudication influences domestic politics and international relations.

This introduction to the Thematic Section defines the theoretical and empirical elements of judicialization. We begin by identifying the defining features and range of adjudicatory institutions-including but not limited to courtsthat contribute to judicializing international relations. We then theorize the effects of judicialization by focusing on the legal processes through which the phenomenon occurs, noting the ways in which those processes empower different actors and follow a different rhythm and logic than classical models of power politics and bargaining. Specifically, we identify four phases of judicialization, classify the key strategies and decision-makers in each phase, and draw upon the contributions to this Thematic Section to illustrate the operation of particular phases. Our goal is to identify key questions and issues to better understand the causes, dynamics, and political consequences of judicialized international relations. We conclude by explaining how the overarching insights of this framework-that states do not fully determine the content, scope, or impact of delegation or adjudication and that legal processes can diminish the role of executives and legislatureshas important implications for the study of international relations and world order.

\section{Judicializing Politics: A Trend (with an End?)}

International law has long been relevant to international relations, even though international enforcement mechanisms are often lacking and international rules are sometimes violated. For example, Isabel Hull (2014) reveals that international legality concerns factored into British decision-making during WWI-long before the creation of most international judicial bodies. Abraham Chayes (1974) documents how, in the 1960s, when adjudication of US foreign policy decisions was an unlikely prospect, international law factored into the Kennedy Administration's closed-door strategic decisions during the Cuban Missile Crisis. Judicialized politics differs from these examples in that governments anticipate that international law violations will give rise to external review by an adjudicatory body.

Our investigation is inspired by the observation that the nature and the extent of judicial involvement in international politics grew tremendously following the Cold War. At the domestic level, there has been a proliferation of constitutional courts (Stone Sweet 2000; Ginsburg 2008), which both reflect and shape a growing culture of legality (Huneeus, Couso, and Sieder 2011), and a global trend in rights-claiming and legal activism (Epps 1998; Halliday, Karpik, and Feeley 2007). The willingness of national judges to adjudicate human rights abuses (Sikkink 2011), to restrict foreign sovereign immunity (Roht-Arriaza 2005; Verdier and Voeten 2015), and to claim extraterritorial jurisdiction has also increased (Raustiala 2009; Putnam 2016). At the international level, the number of permanent international courts has grown (Romano 1999; Alter 2011), as has litigation before both newer and older international courts and arbitral bodes (Alter 2014, 103-7).

The nature of state commitments to external legal review has also changed. States have increasingly accepted compulsory jurisdiction (Romano 2007; O'Connell and VanderZee 2014) and access rules that allow nonstate actors to initiate litigation or arbitration (Alter 2014, 81-85). In addition, international and transnational law are increasingly linked to emerging networks and institutions, such as national human rights institutions (NHRIs) that monitor and promote the implementation of international human rights standards, and the Financial Action Task Force that aims to trace and suppress cross-border money laundering and terrorist financing. Viewed collectively, these changes have increased the possibility of raising formal complaints about state and private actor conduct and policies that violate international law.

The theoretical roots of judicialized international relations are grounded in two distinct traditions. First, we build on the "Legalization and World Politics" special issue of International Organization (IO) (Goldstein et al. 2000, 386). That volume's central claim is that the legal characteristics of international agreements and institutions vary across issue area and time, and both influences are affected by world politics (Abbott et al. 2000). Delegation-which we argue is a necessary but not sufficient condition for judicializationis a central theme in that special issue, and two articles examine how the design of delegation is politically consequential. $^{2}$

Second, we embrace Jeffrey Staton and William Moore's (2011) suggestion that international relations scholars shed the classic assumption that domestic politics is hierarchical while international politics is anarchical, and with it the corollary presumption that legalized domestic politics must be fundamentally different from legalized international politics. Our framework thus builds on comparative

${ }^{2}$ Keohane et al. focuses on the difference between delegation where only states could initiate litigation versus delegation where private actors could seize an international court. Alter discusses factors that generate cross-national and crossissue variation in the invocation and influence of the European Court of Justice (Keohane, Moravcsik, and Slaughter 2000; Alter 2000). We broaden the types of institutions examined and theorize the dynamics that delegation generates. 
judicial politics and comparative law literatures that analyze the growing contribution of domestic courts and rightsclaiming to judicializing domestic politics. ${ }^{3}$ Like international courts, national supreme and constitutional courts have no means to compel governments to follow their rulings (Goldsmith and Levinson 2009). They rely instead on legitimation strategies that create pressure on governments to respect the rule of law and to adhere to judicial rulings. Following these literatures, we accept that legal processesa feature of all functioning legal systems-have their own dynamics and that these processes can be politically consequential because social sanctions (including outcasting and publicly naming policies as illegal) shape state behavior and because legal violations sometimes also give rise to coercive sanctions (Hathaway and Shapiro 2011).

Most of the comparative judicialization literature is courtfocused. As the next section explains, in the international realm a broader array of adjudicatory bodies contribute to judicializing politics. In addition, these bodies often span institutions and borders, making it harder for the executive or legislative branch in any one state to control legal processes that they oppose.

Although judicialization is a global phenomenon, it is neither uniform nor static. There are issue areas where judicialization efforts were never tried or failed (Katzenstein 2014; Romano 2014b; Alter, Helfer, and Madsen 2018; de la Rasilla and Viñuales 2019) and geographic zones where international judicialization is all but absent (Kahler 2000; Kingsbury 2011; Romano 2014a; Romano 2019). Moreover, we are witnessing a period of backlash against these trends. Political resistance to assertions of legal authority-both domestic and international-is hardly new (Alter 2000, 2018a; Helfer 2002; Greenhouse and Siegel 2011). But the current nationalist-populist backlash arguably has a broader resonance and impact than the reactions that preceded it. A strength of our framework is that it incorporates backlash as a type of feedback politics and explores its varied outcomes.

The scope conditions we define below allow us to observe the number and type of adjudicatory bodies, and the four-phase framework we develop helps to conceptualize the political dynamics that drive an expansion or decrease in judicialization. If the conditions for judicializing politics substantially change, we would expect judicialization to also change. Ginsburg and Abebe's (2019) contribution to this Thematic Section addresses this issue, applying our framework in reverse to theorize the conditions that contribute to "dejudicialization" (Ginsburg and Abebe 2019).

The contributions to this Thematic Section focus on specific phases, institutions, and mechanisms. The larger framework, described below, identifies the conditions that contribute to judicializing and dejudicializing international relations.

\section{Scope Conditions for Judicialized Politics}

The existence of adjudicatory bodies that can issue authoritative legal rulings is a necessary condition for politics to become judicialized. A central contribution of our project is to define the types of bodies that can produce this result. We identify four cumulative criteria, summarized in Table 1.

First, the body must decide concrete legal disputes between contesting parties. Second, the body's decision-

\footnotetext{
${ }^{3}$ Whereas American judicial politics scholars have emphasized understanding judicial behavior, the comparative politics literature focuses on the role of courts in influencing politics and policy processes. Examples we build on include: Ferejohn (2002); Epps (1998); Stone Sweet (1992a, 1992b, 2000); Hirschl (2004, 2014); Tate and Vallinder (1995).
}

Table 1. Four criteria of adjudicatory bodies that can judicialize politics

1. Formal authority to decide concrete legal dispute between contesting parties

2. Independent decision-makers that apply preexisting rules and procedures to review facts, evidence, and legal claims

3. Reaches authoritative determinations of violations of law (binding or nonbinding)

4. Orders or suggests actions to remedy legal violations and prevent their recurrence

makers must be formally independent, in that they do not officially represent states and must apply preexisting rules and procedures to the disputes that arise. Third, adjudicators must have the power to authoritatively declare whether violations of the law have occurred. Fourth, the body must have the ability to order or at least suggest actions that the losing party must take to remedy legal violations and prevent their recurrence. Together, these four criteria establish decision-making dynamics that differ from political processes. Adjudicatory bodies that meet these criteria can incentivize potential litigants to raise legal arguments, making their demands for policy change more credible and specific and generating additional pressures on states and national decision-makers to change their policies.

Any adjudicatory body that meets these four criteria is a potential venue for judicializing politics. Since this definition includes national courts that hear cases with international law or transborder dimensions, as well as quasijudicial bodies that do not issue legally binding rulings, it substantially broadens the number and range of actors and institutions that scholars have traditionally recognized as influencing politically consequential outcomes. The definition also identifies institutions that fall outside of these criteria-as might occur, for example, if the second element (independent decision-makers) is compromised-and issue areas, such as arms control, that are unlikely to be judicialized because no adjudicatory body fulfilling all four criteria exists.

In what follows, we briefly discuss a variety of these institutions, highlighting the actors that shape the design decisions that determine whether an institution meets these four criteria. Table 2 categorizes the types of institutions that do and do not satisfy the four criteria, describes their attributes, and provides additional examples.

The twenty-four international courts (ICs) now in operation around the world are the most obvious, and among the most studied, institutions that fulfill the four criteria. The decision of states to delegate adjudicatory powers to ICs brings with it important and consequential design choices, such as which actors can file complaints, the criteria for electing or selecting judges, which international law violations judges can review, and the kinds of remedies they award. ${ }^{4}$ These design decisions affect whether and how the existence of an IC motivates rights-claiming for a particular issue. For example, if a court lacks compulsory jurisdiction or can only award limited remedies, this may inhibit whether the threat of litigation is credible and thus, in turn, whether actors mobilize to assert legal rights and judicialize the issue.

While states define key elements of an IC's jurisdiction and access rules, international judges have themselves expanded their reach by broadly interpreting these rules, enhancing their remedial powers, and diminishing the

${ }^{4}$ For studies seeking to explain the design choices for international adjudicatory institutions, see McCall Smith (2000); Allee and Elsig (2016); Koremenos and Betz (2013); Hooghe et al. (2016). 
Table 2. Types of institutions that contribute to judicialized politics

\begin{tabular}{|c|c|c|}
\hline Category & Attributes & Examples \\
\hline \multicolumn{3}{|l|}{ Adjudicatory bodies } \\
\hline $\begin{array}{l}\text { International courts } \\
\text { and tribunals }\end{array}$ & $\begin{array}{l}\text { - Created mainly by state delegations in treaties } \\
\text { - Adjudicate complaints in disputes alleging violations of } \\
\text { international law } \\
\text { - Issue legally binding rulings and advisory opinions } \\
\text { - May indicate remedies for violations }\end{array}$ & $\begin{array}{l}\text { - International Criminal Court } \\
\text { - International Court of Justice } \\
\text { - International Criminal Tribunal for the Former } \\
\text { Yugoslavia } \\
\text { - Appellate Body of the World Trade Organization } \\
\text { - European Court of Human Rights } \\
\text { - East African Court of Justice }\end{array}$ \\
\hline National courts & $\begin{array}{l}\text { - Preexisting judicial institutions within a national legal } \\
\text { system } \\
\text { - Adjudicate complaints in disputes alleging violations of } \\
\text { international law, extraterritorial application of } \\
\text { domestic law, or transnational contracts or torts } \\
\text { - Issue legally binding rulings } \\
\text { - Order remedies for violations }\end{array}$ & $\begin{array}{l}\text { - National trial or appellate courts with jurisdiction over } \\
\text { violations of international law or disputes raising } \\
\text { transborder legal issues } \\
\text { - Specialized national courts with jurisdiction over } \\
\text { international law or transborder legal issues (e.g., US } \\
\text { Court of International Trade, criminal courts of East } \\
\text { Timor and Kosovo, China's Belt and Road courts) }\end{array}$ \\
\hline $\begin{array}{l}\text { International } \\
\text { arbitration }\end{array}$ & $\begin{array}{l}\text { - Established by arbitral institutions or ad hoc } \\
\text { - Reviews disputes involving violations of international } \\
\text { law or contracts with transborder aspects } \\
\text { - Issue legally binding awards } \\
\text { - Remedy for violations is usually monetary damages }\end{array}$ & $\begin{array}{l}\text { - International Center for the Settlement of Investment } \\
\text { Disputes } \\
\text { - Permanent Court of Arbitration } \\
\text { - Hong Kong International Arbitration Centre } \\
\text { - Ad hoc arbitration under the UN Commission on } \\
\text { International Trade Law (UNCITRAL) Rules }\end{array}$ \\
\hline Quasi-judicial bodies & $\begin{array}{l}\text { - Created by treaties or IOs } \\
\text { - May perform both judicial and nonjudicial functions } \\
\text { - For judicial functions, review communications in } \\
\text { disputes alleging violations of international law } \\
\text { - Issue nonbinding decisions identifying legal violations } \\
\text { - May recommend remedies for violations }\end{array}$ & $\begin{array}{l}\text { - UN human rights treaty bodies } \\
\text { - NAFTA binational panels } \\
\text { - Complaint procedures of national human rights } \\
\text { institutions } \\
\text { - Implementation Committee of Montreal Protocol on } \\
\text { Substances that Deplete the Ozone Layer } \\
\text { - World Bank inspection panels } \\
\text { - Eritrea-Ethiopia Claims Commission } \\
\text { - ILO Committee on Freedom of Association }\end{array}$ \\
\hline \multicolumn{3}{|c|}{ Non-adjudicatory institutions } \\
\hline $\begin{array}{l}\text { International political } \\
\text { bodies }\end{array}$ & $\begin{array}{l}\text { - Established by treaty or international organization } \\
\text { - Adopt resolutions and decisions applicable to member } \\
\text { states }\end{array}$ & $\begin{array}{l}\text {-UN Security Council } \\
\text {-UN General Assembly } \\
\text {-UN Human Rights Council } \\
\text { - Council of the European Union } \\
\text { - ECOWAS Council of Ministers }\end{array}$ \\
\hline $\begin{array}{l}\text { International } \\
\text { investigation, } \\
\text { compliance, and } \\
\text { norm-development } \\
\text { institutions }\end{array}$ & $\begin{array}{l}\text { - Established by a treaty } \\
\text { - Review state party reports } \\
\text { - Document patterns of international law violations } \\
\text { - Investigate possible violations of international law } \\
\text { - Suggest new international legal norms }\end{array}$ & $\begin{array}{l}\text { - International Atomic Energy Agency } \\
\text { - Conference of the Parties (CoP) of the Convention on } \\
\text { International Trade in Endangered Species of Wild } \\
\text { Fauna and Flora (CITES) } \\
\text { - International Law Commission's preparation of draft } \\
\text { treaties }\end{array}$ \\
\hline $\begin{array}{l}\text { Mediation and } \\
\text { conciliation bodies }\end{array}$ & $\begin{array}{l}\text { - Assist states and private actors in amicably resolving } \\
\text { disputes } \\
\text { - Do not issue a decision identifying legal violations }\end{array}$ & $\begin{array}{l}\text { - WIPO Arbitration \& Mediation Center } \\
\text { - Singapore International Mediation Centre } \\
\text { - Mediation and conciliation by National Human Rights } \\
\text { Institutions, such as the South African Human Rights } \\
\text { Commission }\end{array}$ \\
\hline $\begin{array}{l}\text { Administrative review } \\
\text { bodies }\end{array}$ & $\begin{array}{l}\text { - Created by a treaty or international organization } \\
\text { - Receive and review requests from nonstate actors } \\
\text { - Prepare factual findings } \\
\text { - Do not identify legal violations } \\
\text { - Forward factual findings to other bodies for further } \\
\text { review }\end{array}$ & $\begin{array}{l}\text { - Ombudsperson reviews of requests for removal from } \\
\text { lists adopted by UN Security Council Sanctions } \\
\text { Committees } \\
\text { - Factual records prepared by the commissions of } \\
\text { NAFTA labor and environment side agreements }\end{array}$ \\
\hline
\end{tabular}


discretion of states and their officials (Weiler 1991; Burley and Mattli 1993; Alter and Helfer 2010; Huneeus 2013). For example, Staton and Romero's contribution to this Thematic Section considers how judicial choices regarding remedial orders influence human rights politics in Latin America. They espouse a model of judicial opinion writing that connects the clarity of legal rulings to both the informational challenges judges face and the likely reaction by national actors (governments and judges) to those rulings. (Staton and Romero 2019). Larsson and Naurin's contribution investigates how multidimensional alignments of interests across shifting coalitions of European Union (EU) members give the Court of Justice of the European Union interpretative latitude that limits state discretion (Larsson and Naurin 2019).

Scholars have long studied why states consent to international judicial review (Moravcsik 1995, 2000; Helfer and Slaughter 2005; Helfer 2006; Koremenos 2008) and the factors that influence the design of ICs. What this literature omits, however, are the diversity of other adjudicatory bodies that can influence international politics, as well as the different phases in which these bodies shape actor incentives. $^{5}$

An often overlooked category of adjudicators are national courts that hear cases involving violations of international law and transborder legal issues, such as the extraterritorial application of US securities or antitrust statutes, suits challenging Argentina's failure to repay its sovereign debt, or the enforcement of foreign judgments and international arbitral awards, including against states. ${ }^{6}$ In countries in which ratified treaties have automatic domestic effect, national courts can review international law claims directly. In others, judges interpret treaties indirectly via implementing legislation and by interpreting domestic statutes consistently with international law (Alford 2006; Szewczyk 2014; Alter 2018b). The extent to which national courts directly or indirectly apply international law varies. In this Thematic Section, Lupu, Verdier, and Versteeg identify two legal tools that national judges can employ in suits alleging violations of international human rights law, explain how these tools influence whether and how those violations are adjudicated, and test whether the availability of these tools influences the relationship between treaty ratification and human rights abuses (Lupu, Verdier, and Versteeg 2019). ${ }^{7}$

International arbitral bodies are a third type of adjudicatory institution. Individuals, corporations, and governments often prefer private decision-makers to handle legal disputes, choosing arbitration over judicial venues. Some treaties make arbitration the default mode of dispute resolution. Many bilateral investment treaties, for example, authorize foreign firms to use international arbitration to challenge host-state regulations (Büthe and Milner 2014; Hafner-Burton, Steinert-Threlkeld, and Victor 2016). Investment arbitration has been increasingly criticized, and Ginsburg and Abebe identify states that have refused to consent to investor-state dispute settlement (Ginsburg and Abebe

\footnotetext{
${ }^{5}$ The Oxford Handbook of International Adjudication includes international courts and international arbitration but excludes quasi-judicial bodies (Romano, Alter, and Shany 2014). In earlier work, Romano provided a helpful list of both judicial and quasi-judicial international bodies Romano (2011).

${ }^{6}$ Another example is the domestication of the Rome Statute creating the International Criminal Court via national laws that authorize domestic prosecutions of genocide, war crimes, and crimes against humanity committed at home or abroad. On the growth of extraterritorial law enforcement, see Raustiala (2009); Putnam (2016); Bookman (2015, 1108-19).

${ }^{7}$ See also Verdier and Versteeg (2015); Bookman (2015).
}

2019).$^{8}$ Yet, there is an entire world of international commercial arbitration beyond the realm of investment disputes. Arbitration implicates a set of customizable design choices selected by the drafters of a treaty or contract, including the applicable substantive rules, the "seat" where proceedings occur, and whether claims are heard by a permanent institution or ad hoc panels. These decisions can also affect whether and where litigation to enforce arbitral awards occurs.

A fourth category comprises quasi-judicial bodies that are similar to ICs with one exception-they do not issue legally binding rulings. For example, the ten United Nations (UN) human rights treaty bodies review complaints against states by individuals and NGOs, issue reasoned decisions identifying violations, and recommend remedies (Hafner-Burton 2013). Although nonbinding, these decisions and recommendations can mobilize actors and influence political outcomes in much the same way as judicial rulings (Kirby 2001; Hafner-Burton 2012; van Alebeek and Nollkaemper 2012). A further expansion of quasi-judicial bodies, and of rightsclaiming, has occurred at the domestic level via a network of National Human Rights Institutions, many of which allow individuals to file complaints challenging human rights violations committed by government agencies or officials (Linos and Pegram 2016; 2017). Quasi-judicial bodies are also found in other issue areas of international law, including environmental protection, finance, labor, and trade (Tignino 2016; Chiara 2017).

We emphasize that many familiar international institutions fall outside of this definition or occupy grey areas that meet some but not all of the four criteria. Table 2 identifies the key attributes of institutions that do and do not meet our definition.

Table 2 illustrates several core insights of the judicialization framework. First, although some adjudicatory bodies are created by state delegations, many are not. Agreements to arbitrate, for example, may be the result of private contracting, and national court litigation of international or transborder suits often occurs without explicit state authorization. Moreover, national courts and arbitral bodies may also apply domestic law or private contacts, diminishing the role of executives or legislatures in making decisions relevant to international affairs (Büthe and Mattli 2011).

Second, states do not fully determine the content and scope of the delegation. While states sometimes augment or shrink an IC's jurisdiction (such as by adding the crime of aggression to the Rome Statute), adjudicatory bodies themselves can extend a body's reach in ways that states neither intended nor anticipated. For example, many national legal systems, national courts may apply international law directly and give it primacy over domestic laws, a broad delegation that gives these courts considerable discretion (Verdier and Versteeg 2015). The existence of multiple venues also introduces an iterative dynamic to judicialized politics. Litigants can shift adjudication across venues, such as from ICs to arbitration, or quasi-judicial bodies to national courts, and litigants and judges may adjust their legal interpretations and strategies in response to the decisions of other adjudicatory bodies (Helfer 1999; Hafner-Burton 2005a). This is another way in which judicialization can diminish state influence.

\footnotetext{
${ }^{8}$ Recent debates regarding investment treaty arbitration focus on whether arbitrators privilege the rights of foreign investors over other domestic laws and policies, such as environmental, public health, and consumer protection. Critics charge that international arbitration has a chilling effect on domestic policymaking (Rogers 2013), and their concerns have generated a search for alternative ways to resolve treaty-based investment disputes (Roberts 2018).
} 
Table 3. Four phases of judicialized politics

\begin{tabular}{|c|c|c|}
\hline Phase & Key actors & Strategies \\
\hline Shadow politics & $\begin{array}{l}\text { - Litigants with legal standing (states, individuals, firms, } \\
\text { and/or NGOs or interest groups) } \\
\text { - Government agencies or officials } \\
\text { - Legal and other representatives of these actors }\end{array}$ & $\begin{array}{l}\text { - Mobilize and frame claims and arguments using legal } \\
\text { language and rights-claiming } \\
\text { - Engage in out-of-court negotiations with the threat of } \\
\text { adjudication in the background } \\
\text { - Defensive actions to avoid or improve litigation } \\
\text { outcomes }\end{array}$ \\
\hline Adjudication politics & $\begin{array}{l}\text { - Parties to the dispute } \\
\text { - Third-party interveners (e.g., amicus briefs) } \\
\text { - Adjudicators (judges, arbitrators, or members of } \\
\text { quasi-judicial bodies) }\end{array}$ & $\begin{array}{l}\text { - Litigants select cases, venues, evidence, and legal } \\
\text { arguments } \\
\text { - Out-of-court defensive actions to influence adjudicators } \\
\text { and shape adjudication outcomes } \\
\text { - Adjudicators choose interpretive rules, determine legal } \\
\text { violations, and indicate potential remedies }\end{array}$ \\
\hline Compliance politics & $\begin{array}{l}\text { - Parties to the dispute } \\
\text { - Interest groups that favor or oppose compliance } \\
\text { - Government agencies or officials asked to comply with } \\
\text { rulings }\end{array}$ & $\begin{array}{l}\text { - Post-litigation bargaining } \\
\text { - Public amplification strategies (e.g., media campaigns, } \\
\text { follow-on investigations, copycat suits) } \\
\text { - Follow-on enforcement proceedings before national } \\
\text { and international courts } \\
\text { - Retaliation and issue linkages if noncompliance persists }\end{array}$ \\
\hline Feedback politics & $\begin{array}{l}\text { - Parties to the dispute } \\
\text { - Politicians and interest groups that want to expand or } \\
\text { undercut future litigation } \\
\text { - Adjudicators in parallel legal bodies (judges, } \\
\text { arbitrators, or members of quasi-judicial bodies) }\end{array}$ & $\begin{array}{l}\text { - Spillover to issues presenting similar legal violations } \\
\text { - Modification of laws and institutions to generalize, } \\
\text { preempt, hinder or weaken future litigation. } \\
\text { - Backlash: reframing and organizing } \\
\text { countermobilizations against unwanted legal rulings } \\
\text { - Dejudicialization: states withdraw from or terminate a } \\
\text { treaty or strip jurisdiction }\end{array}$ \\
\hline
\end{tabular}

Third, the criteria and the list of nonjudicial bodies underscores the ways in which adjudication, and the politics it inspires, can be degraded. States can sometimes reassert control by tasking political bodies to make factual determinations about violations of international agreements or by creating specialized review mechanisms to siphon a class of cases away from existing international review bodies. In addition, mediation, conciliation, and internal administrative processes provide alternative approaches to resolve disputes that may not apply preexisting rules and procedures or may not be politically independent. These qualities contribute to the sense that politics, rather than law, shapes these processes.

\section{Phases of Judicialized Politics}

The two necessary conditions for judicializing international politics involve delegation to an adjudicatory institution and legal rights-claiming. The previous section identified the adjudicatory bodies that fall within our framework. Here, we focus on rights-claiming and the politics it engenders, analyzing and illustrating four phases of the process. As we explain, each phase turns on the decisions of different key actors, such as adjudicators, winning and losing parties, potential litigants, interest groups, and collectivities of states. Executives and legislators cannot determine when potential litigants engage in legal rights-claiming or how judges respond to their arguments because these actions, as well as compliance and feedback politics, can be affected by multiple factors beyond their control.

The transnational nature of adjudication involving international law illustrates why the judicialization of international relations is a different phenomenon than the judicialization of domestic politics. At the domestic level, executive and legislative branches can more easily reclaim a central, if not exclusive, role in politics. Populist leaders in Venezuela, Poland, Hungry, Turkey, and Russia have offered "worst practices" guidebooks on how to reclaim executive prerogatives (Scheppele 2017). Yet, because the adjudicatory bodies we discuss exist outside of national legal orders, these strategies are more difficult to execute. This is in large part because other states, which are themselves often pressured by nonstate actors, may reject efforts to undermine international adjudicatory bodies.

In what follows we focus on politics within each phase. But we also explain the interactive effects across phases. Table 3 previews the four phases and the key actors, strategies, and outcomes associated with each phase.

Shadow politics-the first phase-refers to mobilization, bargaining, negotiations, and responses generated by a plausible threat of adjudication. ${ }^{9}$ Such threats empower potential litigants and increase the risks associated with arguably illegal behavior, thereby shaping the incentives of actors and the voices of those with the law on their side. The primary actors involved in shadow politics include government agencies or officials that are potential targets of lawsuits or arbitration, as well as individuals, interest groups, firms, and states that assert legal claims, issue formal demands for policy changes, and engage in out-of-court negotiations.

The strategies that these actors deploy include framing rights-claims in legal terms, threatening adjudication, identifying adverse policy consequences linked to law violations, and offering settlements or adjusting policies to ward off litigation. For example, in Colombia both proponents and opponents of the peace accord between the government and

\footnotetext{
(1979).

${ }^{9}$ The term shadow politics draws inspiration from Mnookin and Kornhauser
} 
the Revolutionary Armed Forces of Colombia-People's Army (FARC) rebels have used litigation threats and court challenges to bolster their respective arguments, mobilize supporters, and sway referenda on the peace agreement. The strategies, terms, and viability of recent peace accords in Colombia have also been shaped by the prospect of an investigation by the International Criminal Court (ICC), by litigation threats before the Inter-American Court of Human Rights, and by suits in Colombian courts alleging violations of international and domestic law (Huneeus 2018).

Another example of shadow politics is unfolding in response to President Trump's decision to withdraw from the Joint Comprehensive Plan of Action, an agreement in which Iran committed to the monitored cessation of its nuclear program in exchange for the five permanent members of the UN Security Council and the EU lifting economic sanctions against that country. After exiting the agreement, the Trump administration reinstated sanctions, including against non-US companies that do business in or with Iran. The remaining signatories have pledged to uphold the agreement, and US sanctions may run afoul of a Security Council resolution that gives effect to the Iran nuclear deal(Nephew 2018). In addition, Iran has asked the International Court of Justice to order the United States to lift the sanctions (van den Berg and Sterling 2018), and the EU has enacted legislation to bar European companies from complying with the sanctions(Davenport 2018). As this article goes to press, businesses are assessing their legal risks in anticipation of the restored sanctions and lawyers are mobilizing to advise clients in multiple jurisdictions(BlankRome 2018).

A different aspect of shadow politics involves efforts to avoid adjudication. Settlement may well be the most common-yet one of the least studied-manifestation of judicialized politics (Hafner-Burton, Puig, and Victor 2017). Such bargaining can be akin to diplomacy and negotiation, occurring outside of public view (Risse, Ropp, and Sikkink 1999, 2013). Judicialized shadow politics is distinctive, however, in that a third-party adjudicator stands ready to review claims that the parties cannot resolve themselves. Politics may become judicialized even if the defendant does not recognize a legal threat as such; authoritarian leaders, for example, often dismiss the relevance of legal claims and adverse court rulings. But where international law violations can be adjudicated, even recalcitrant defendants often respond with a counterstrategy designed to avoid, derail, or blunt the impact of adjudication.

Scholars have analyzed bargaining in the shadow of WTO dispute settlement, where states must engage in consultations before adjudication commences(Busch and Reinhardt 2000a, 2000b, 2006; Reinhardt 2001; Steinberg 2002; Davis and Blodgett Bermeo 2009). Studies examine the politics of consultations, follow-up litigation decisions (Reinhardt 1999; Davis 2012), how developing countries seek to strengthen their bargaining position (Shaffer 2003; Shaffer, Badin, and Rosenberg 2008; Halliday and Shaffer 2015), and which countries are politically advantaged by threatening to file a WTO suit (Davis and Blodgett Bermeo 2009). There is also an extensive literature on human rights advocacy strategies, although much of it is focused on political pressure rather than on litigation threats. ${ }^{10}$ For other issue areas, scholars have focused on outcomes that follow adjudication rather than those triggered by the threat of suit.

\footnotetext{
${ }^{10}$ Literature that does focus on the legal component includes: Sieder, Schjolden, and Angell (2005); Sikkink (2005); Hafner-Burton (2013); HafnerBurton, Victor, and Leveck (2016); Helfer and Voeten (2014); Hafner-Burton and Tsutsui (2005).
}

Shadow politics raises important questions for international relations scholars: What makes some legal threats more plausible than others? Which actors seize on opportunities to press their legal claims out of court? Perhaps most importantly, when and how is the threat of adjudication enough to influence the behavior of powerful actors, such as multinational corporations, heads of state, or militaries?

Adjudication politics - the legal phase of judicializationencompasses the factors, strategies, and consequences associated with the decision to adjudicate, including which suits are filed, the selection of venue, the gathering of evidence and presentation of arguments, and the decisions of judges, arbitrators, and other adjudicatory bodies. Adjudicators become the dominant actors at this phase, and their independence becomes especially relevant (Brinks and Blass 2017). Because adjudicators determine the outcome of disputes, states must draw on discursive arguments, legal interpretations to shape judicial rulings, and out-of-court maneuvering, which may change the facts on the ground. Such arguments, and the interpretations they generate, can produce politically consequential and enduring outcomes.

Initially, international relations scholars ignored adjudication politics, arguing that preexisting state interests and interstate bargaining determines the resolution of legal disputes (for example, Garrett and Weingast 1993). Our project interjects the litigation process into this inquiry, examining how legal proceedings can be shaped by forces that include the strategic decisions of litigants, the involvement of third parties, and the decision-making choices of adjudicators.

We are only beginning to understand the reasons motivating the initial decision to adjudicate. For example, recent studies of territorial disputes have found that states often adjudicate territorial claims to surmount festering border disputes with neighbors, shift blame to external actors, or secure land rights to attract foreign investment (Simmons 2002, 2005, 2006; Allee and Huth 2006; Huth and Allee 2006). In international trade, states initiate WTO litigation to show domestic audiences that they are defending their economic interests (Davis and Blodgett Bermeo 2009; Davis 2012), to create bargaining chips for future cases, or to shape jurisprudence in ways that advance their interests (Pelc 2014). For example, states may file suit with the WTO to create a precedent that applies to other countries and similar legal issues, but prefer negotiated settlements when seeking a one-off resolution of a dispute (Busch 2007). Private litigants select venues based on factors including the types of remedies available, prior application of international law, and the likelihood of enforcing judgments (Helfer 1999; Alter and Vargas 2000; Hafner-Burton 2005b; Pauwelyn and Salles 2009). These are helpful beginnings, but we still lack systematic studies of adjudication strategies by the contesting parties. We also need greater clarity about whether these insights hold across different types of cases, litigants, and issue areas, as well as how the parties select among available venues, including less visible modes of dispute resolution.

Scholars have also examined the factors shaping judicial decision-making (for example Pauwelyn and Elsig 2012; Stone Sweet and Brunell 2012; Larsson and Naurin 2016). In this Thematic Section, Lupu, Verdier, and Versteeg explore how national judges modulate their decisions to avoid political backlashes and enhance the extent to which international human rights law is given direct effect. Their finding suggests that variations in national judicial decision-making as well as the substance of the law (e.g., the 
particular human right at stake) can have important consequences for determining whether, how, and to what extent international rules shape domestic policy (Lupu, Verdier, and Versteeg 2019). Larsson and Naurin, in their study of the Court of Justice of the European Union (CJEU), venture beyond traditional behavioral approaches to examine the relationship between varying state preferences for retaining sovereignty and distributional concerns about European social policies. This approach helps to identify when the CJEU should worry about political backlash and when its judges have greater political latitude. Their study reveals the underappreciated point that the preferences of states and nonstate actors who do not participate in adjudication also shape IC decision-making (Larsson and Naurin 2019).

Other contributions to this Thematic Section analyze how decisions made in the adjudication phase are related to later phases of judicialization. In the context of the InterAmerican Court of Human Rights, Staton and Romero explore how the adjudication and compliance phases of judicialization are deeply intertwined, revealing that judges strategically attempt to influence state reactions to their rulings through manipulating their choice of language in judicial opinions (Staton and Romero 2019). In a similar vein, Busch and Pelc use automated text analysis to examine the incidence of affective terms in WTO Appellate Body rulings. They argue that this international court employs affectladen phrases to offer governments normative resources to persuade domestic audiences to comply with its rulings. The authors find that affective terminology is more prevalent for trade disputes that encroach on politically sensitive topics, such as health and environmental standards, and that it varies systematically according to the legal issue at stake, suggesting an awareness by adjudicators of the risks of judicializing issue areas traditionally reserved for domestic regulation (Pelc and Busch 2019).

Compliance politics-the third phase-refers to the strategies and actions of the litigants or other actors who press for or against adherence to legal rulings. Decisions by governments about whether, when, and how to comply with the law often shift once an IC or other third-party adjudicator has issued a ruling. By naming a certain policy or action as a violation, such rulings undercut the legitimacy of the condemned action. By specifying what compliance with the law requires, adjudication narrows the plausible arguments for maintaining a policy and creates a focal point for pressuring respondents (often states) to change their behavior.

Pundits often suggest that major policy changes necessarily-or likely-follow an adverse legal ruling. Scholars of judicial politics, however, know that the impact of legal rulings can be nonexistent, indirect, unintended, delayed, or difficult to discern (Rosenberg 1993). Numerous factors influence how post-litigation compliance politics unfolds. The key actors in this phase shift back to the litigants. Immediately following a ruling, losing defendants have a choice. They may accept the financial or political costs of continued noncompliance, agree to only symbolic concessions, or seek more time by creating an inadequate or feigned implementation response, as Japan did when it initially sought to define itself out of complying with an ICJ ruling (Butler-Stroud 2016). ${ }^{11}$ The choice among these decisions can trigger further litigation in which adjudicators are asked to declare additional remedies or to moderate the remedies they previously demanded.

Should the state fall short, a broader set of actors may mobilize to push for full compliance. States that did not

\footnotetext{
${ }^{11}$ See also Hafner-Burton and Tsutsui (2004).
}

participate in the litigation may retaliate, apply preexisting domestic provision that withdraw benefits (such as aid, market access, new agreements or political exchanges) so long as the violation persists. NGOs can use the violation for mobilization and political leverage (e.g., with legislators and local officials). International institutions can factor the violation into their decision-making. Legal rulings may also be enforced in different venues, including domestic courts in countries where assets are held. All of these actions can increase the costs of flouting a ruling. ${ }^{12}$

As this discussion reveals, compliance politics are much larger than the question of whether or not a state follows a particular ruling. This binary question is often far too simplistic, especially because compliance is often partial (Hawkins and Jacoby 2010). The key analytical inquiry of this phase is whether, when, and how adjudication becomes a useful tool to promote respect for the law. Examining compliance may require that scholars recognize that the preferences of governments and other powerful actors are not always the only, or even the primary, factors shaping compliance politics and compliance decisions. ${ }^{13}$ Studying compliance politics helps to explain why judicialization shifts power away from executives and why political leaders respond to adjudication by making arguments and policy decisions that can have unintended or unanticipated consequences.

Several articles in this Thematic Section speak to state compliance. For Staton and Romero (2019), noncompliance with a judicial ruling is not necessarily a sign that a court-in their case, the Inter-American Court of Human Rights-is weak; rather, it reflects a need in the adjudication phase to reduce the clarity of legal rulings in the face of political uncertainty surrounding how to effect policy change. Similarly, for Pelc and Busch (2019), one reason that WTO rulings are often laden with affective language is to strategically provide governments a resource to mobilize pro-compliance interest groups around those rulings where compliance is likely to be a political struggle. The trade-off for doing so is that such language may encourage compliance in a specific case but reduce the case's applicability beyond the dispute at hand. Lupu, Verdier, and Versteeg (2019) seek to explain how national variation in how judges apply international law also affects compliance with human rights. Trying to deter backlash politics in the feedback phase of judicialization, national judges act strategically in the adjudication phase to shape the degree of compliance.

The study of compliance per se has been strongly and justifiably critiqued (Checkel 1999; Börzel 2001; Howse and Teitel 2010; Martin 2013). Yet, respect for legal rulings still matters. New questions about compliance politics are arising as governments seek to limit judicial interference in their agendas. For example, the European Court of Human Rights (ECtHR) has issued judgments against European governments that assisted the United States in detaining suspected terrorists at "black sites" and rendering them to third countries (BBC 2018), and the ICC prosecutor opened an investigation that included similar allegations as well as potential war crimes in Afghanistan(Moorehead and Whiting 2018). These rulings may complicate any attempt by the Trump Administration to

\footnotetext{
${ }^{12}$ Hathaway and Shapiro discuss a range of social sanctions that are used as part of "outcasting" to signify often less formal means to pressure for compliance (Hathaway and Shapiro 2011). See also Harlow and Rawlings (1992).

${ }^{13}$ This idea is further developed in Alter et al. (2018), which focuses on how contextual factors beyond the control of judges and governments affect IC authority, influence, and power.
} 
revive "enhanced interrogations." International courts are also being asked to weigh in on government restructuring of national judiciaries. The CJEU recently ruled that national judges can block extradition requests to Poland due to concerns that criminal trials in that country are unfair, and the EU Commission launched an infringement action to protect the independence of the Polish Supreme Court, which has been threatened by executive interference(Court of Justice of the European Union 2018). These examples reveal how judicial rulings, by providing future litigants with validated legal claims and by facilitating external sanctions, provide signals intended to deter future noncompliance.

Feedback politics-the strategies and actions that follow from a legal victory or loss-reflect the fact that adjudication generates a precedent that can create a new political status quo. There are two forms of feedback politics. Positive feedback seeks to amplify a legal ruling applicable only to the parties into a larger policy change or to new legal obligation that is owed to all. ${ }^{14}$ Backlash politics tries to overturn a precedent, abrogate or circumvent a ruling, or avert future losses in similar cases. ${ }^{15}$ Although contestations over compliance may take months or even years to play out, feedback politics can take even longer, becoming fully evident only when publics inculcate a legal ruling, new actors enter the political arena, or legal entrepreneurs attempt to broaden the impact of a precedent.

An example of feedback politics that includes both positive and backlash elements is the landmark 1980 decision of the US court of appeals in Filártiga $v$. Peña-Irala. ${ }^{16}$ That ruling included two provocative findings. First, the court revived a seemingly dead letter of American law, the Alien Tort Statute, to adjudicate human rights claims by foreigners. Second, the court held that the ban on torture was part of customary international law. The case laid the groundwork for the Torture Victim Protection Act, a 1991 statute that codifies the right to sue foreign officials who torture foreigners or US citizens and extends Filártiga to extrajudicial killings. ${ }^{17}$ The revival of the Alien Tort Statute triggered dozens of lawsuits against states, corporations, and private individuals. These rulings also engendered backlash effects, leading the US Supreme Court to sharply limit the statute in recent years and shield these actors from liability(Samp 2018). As a result, the right for torture victims to sue for damages is now entrenched in US law, yet the extension of these rights vis-à-vis corporations has been curtailed.

Positive feedback and backlash effects may arise during other phases of judicialization, regardless of whether a complaint results in a final legal ruling. For example, bargaining in the shadow of adjudication may lead to out-of-court settlements that enhance respect for the law or, alternatively, create new policies that eliminate the ability to file complaints. Adjudication politics may spread a single legal victory across a class of similarly situated actors or engender new complaints that elicit more expansive legal rulings. Conversely, such follow-on processes may lead adjudicators to narrow prior findings, limit remedies, or discourage future litigation.

\footnotetext{
${ }^{14}$ Lawyers label this as an erga omnes effect. For a study of the erga omnes effects of international court rulings, see Helfer and Voeten (2014).

${ }^{15}$ In the $I O$ legalization volume, Alter (2000) considers both forms of feedback effects. For literature on backlash, see Helfer (2002); Alter, Gathii, and Helfer (2016); Madsen, Cebulak, and Wiebush (2018).

${ }^{16}$ Filártiga v. Peña-Irala, 630 F.2d 876 (2d Cir. 1980).

${ }^{17}$ Torture Victim Protection Act of 1991, Pub. L. No. 102-256, 106 Stat. 73 (1992). The Act also adds detail, including statutes of limitations and exhaustion of domestic remedies, that constrain post-Filártiga adjudication. See Apostolova (2010).
}

In this Thematic Section, Lupu, Verdier, and Versteeg (2019) theorize about how judges seek in the adjudication phase to strategically avoid backlash. Ginsburg and Abebe (2019) consider whether the expansion of judicialized politics in the 1990s later contributed to dejudicialization-a term they define as extreme instances of backlash in which states remove areas of law from external judicial review. Building on the domestic judicial politics literature and literature on backlash against international courts (see footnote 15), Ginsburg and Abebe offer a conceptual framework for thinking about how dejudicialization occurs.

\section{Politics between and across the Four Phases}

International relations is a famously state-centric discipline. Studying the individual phases of judicialization sheds light on several understudied issues-how nonstate actors as well as states deploy international legal claims to bargain out of court, how adjudicators rule, and whether and how the parties comply with or resist new legal interpretations that international adjudication generates. While venues, actors, and politics at each phase differ, actors may attempt to build connections across the phases to achieve their goals. Since cases can settle at any time, there is no necessary progression from one phase to the next. But there are interactive effects based on expectations of events later in the process (Alter 2014, 59-60).

Viewed collectively, the contributions to this Thematic Section highlights a more basic point: decisions at any point in the adjudication process - from delegation, to the choice of whether to sue, and how, if at all, to comply with a ruling-can have effects that are neither direct nor immediate nor fully under the control of governments. Adjudication can shift the meaning of legal rules, providing a mode of policy and institutional change that may be easier to orchestrate because it does not require multilateral agreement. ${ }^{18}$ Legal rights-claiming and participation in adjudication can also deepen political commitments and lead to more fundamental changes in how actors conceive of their rights and interests (Goodman, Jinks, and Woods 2012; Goodman and Jinks 2013). ${ }^{19}$

Transnational litigation of LGBT rights illustrates this point. The last two decades have seen numerous domestic and international court rulings decriminalizing samesex relations and requiring governments to recognize samesex marriages. In addition to changing national policies in individual countries, the shadow of adjudication has shaped transborder strategies to promote LGBT rights. Helfer and Voeten (2014) document the effect of ECtHR rulings on LGBT rights in countries across Europe, including those whose laws were not subject to judicial challenge. LGBT advocacy is spreading to other regions. A 2018 InterAmerican Court of Human Rights advisory opinion on gender identity and same-sex marriage is already being implemented by national judges in Latin America(Contesse 2018; Thapa, Saurav Jung 2018), and a groundbreaking unanimous judgment of the Supreme Court of India cites to earlier pro-LGBT rulings to invalidate the country's colonialera sodomy law, emboldening litigants to challenge similar laws across Asia and Africa(Suri 2018).

These examples of politics inspired or shaped by adjudication highlight how judicialization makes law a distinct kind of norm (Keohane 1997; Finnemore 1999). Knowing

\footnotetext{
${ }^{18}$ Reinterpretation is one of the modes of institutional change identified in the historical institutionalist scholarship (Streeck and Thelen 2005).

${ }^{19}$ The literature on victim participation in mass atrocities prosecution also proceeds from this premise. See Hoven and Scheibel (2015).
} 
more about the influence of these processes and nonstate actors, as well as how adjudicators navigate the discretion available to them, can help to better understand how judicialized outcomes differ from political bargains not refracted through the legal process. For example, does participation in legal rights-claiming and adjudication, and the results it generates, influence how state and nonstate actors frame and articulate preferences both inside and outside of court? When is framing a state action as a violation of international law (e.g., as a war crime or a human rights abuse) helpful and when is this framing counterproductive (Cloward 2014; Helfer and Showalter 2017)? Answering such questions may also contribute to scholarship on the spread of norms, knowledge, and ideas through legal processes, as well as to emerging behavioral studies that examine how the personal traits of individual political leaders, officials, and judges shape international relations (HafnerBurton et al. 2017).

\section{When Judicialized Politics Matter}

This Thematic Section uses a range of methodologies to investigate the processes and effects of judicializing international politics. In the past, states relied on their own assessments of what actions international law requires. These assessments tended to be shaped by each government's material, political, and strategic interests, leading to self-serving interpretations that privileged national sovereignty. In contrast, where international politics is judicialized, litigation and litigation threats become tools of influence. Political leaders must factor in (1) how adjudicators may rule and (2) the material and legitimacy costs should their policies be found illegal.

The relevance of judicialization to international relations stems from its potential to empower new actors, to shift political disputes into legal venues, and to generate discursive and extralegal strategies to influence legal processes, and thereby to affect outcomes of high political saliencesuch as armed conflicts, territorial disputes, trade and investment, human rights, and societal well-being and development. Such influence does not require litigants to pass through all phases of judicialization or any particular phase, such as compliance with a legal ruling. To the contrary, it is possible for international relations to become judicialized in a meaningful way - that is, for adjudicatory bodies to change politics and outcomes in ways that shift away from the preferences of states and their officials-at any phase. However, judicialization is not necessarily limited to particular issue areas, although it is more prevalent and more advanced in some policy spaces than others.

The importance of judicialization for international relations is a matter of degree. The phenomenon becomes potentially important when any phase of the process contributes to a shift in political dialogue, processes, or outcomes over which governments once had exclusive or primary control. Judicialization becomes increasingly politically salient as greater numbers and types of actors enter into the process at different phases, increasing legal rightsclaiming and pressure for policy reforms-as has occurred, for example, when women successfully pressed for the prosecution of rape during wartime (Askin 2003) and for the investigation of mass rape by police(Ahmed 2018). It takes on greater importance when states or other powerful actors respond to rulings by paying compensation or providing other remedies. And it is most consequential when these actors adopt long-term changes on "matters of outright and utmost political significance that often define and divide whole polities" (Hirschl 2008, 94)—such as Brexit and the Colombian government's peace agreement with the FARC.

We stress, however, that judicialization is not a one-way phenomenon. To the contrary, politics can become dejudicialized. In this Thematic Section, Ginsburg and Abebe (2019) focus on when states remove adjudicatory bodies from the political equation, but politics can also become dejudicialized when adjudicators lose their independence (Brinks and Blass 2017) and, more generally, when "legality" becomes less normatively or politically salient, leading governments to worry less about flouting law or legal rulings (Dyzenhaus 2012; Brunnée and Toope 2017; Alter 2019). Meanwhile, dejudicialization may occur alongside rejudicialization. For example, several developing countries have recently withdrawn from treaties that allow foreign corporations to seek international arbitration to challenge domestic policies as violating international investment law (Peinhardt and Wellhausen 2016). But this trend has also contributed to new judicialization proposals, including the European Union's push to create a Multilateral Investment Court (Council of the European Union 2018) ${ }^{20}$ and China's Belt and Road Initiative to create new judicial mechanisms for adjudicating commercial disputes relating to Chinese investments (Hillman and Goodman 2018; Cohen 2018). Similarly, frustration by African political leaders with the International Criminal Court has generated exit threats and actual withdrawals from the Rome Statute, but it has also led to the Malabo Protocol, which will create a criminal law chamber for the proposed African Court of Justice and Human Rights, and it may spur national judges to launch their own war crimes prosecutions (Sirleaf 2017).

\section{Conclusion}

The advent of judicialization beyond national borders marks a fundamental shift in international relations. Whereas in the past foreign ministries may have decided whether and how to advance the legal claims of their nationals, today firms, citizens, and countries are increasingly turning directly to adjudicatory bodies in the hopes of eliciting a legal ruling that vindicates their position. Although some have argued that this shift is permanent, recent events reveal that some governments have responded by mobilizing political resources and strategies to defend their interests. In addition, populist revolts against European integration and globalization more generally may have been exacerbated by the strength of the courts associated with the EU and the WTO and the international arbitral tribunals that hear investorstate disputes by foreign corporations.

These politics may take a long time to fully play out, so that the ultimate impact of international adjudication may not be immediately apparent. For example, China's entry into the WTO and its acceptance of the obligation to adjudicate trade disputes has had many downstream political effects. The United States no longer uses the threat of withdrawing most favored nation market access because China disrespects the human rights of its citizens. The binding and legally enforceable nature of WTO trade rules has constrained responses to increased Chinese imports, contributing to the US and European strategy of negotiating new trade agreements outside of the WTO framework (Dür and Elsig 2015), to the invocation of national security as a justification for limiting imports, to the current US policy of blocking appointments to the WTO

${ }^{20}$ See Multilateral Investment Court: Council gives mandate to the Commission to open negotiations. 
Appellate Body (Shaffer, Elsig, and Pollack 2017), and to a populist backlash against trade liberalization. Most recently, the United States announced its withdrawal from a 144-year-old postal union treaty, because this treaty provides discounted small package shipping rates for Chinese goods sent to the United States(Thrush 2018). The WTO also creates a potential platform for China to take up the mantle of multilateralism that the Trump administration is shedding. These events are not wholly determined by the judicialization processes we discuss. Yet, it is nonetheless the case that the legal rights and obligations associated with China's WTO membership_-and the fact that these rights can be judicially enforced-have been a global political game changer.

The overarching insights of the judicialization framework-that states do not fully determine the content, scope, or impact of delegation or adjudication and that legal process can diminish the role of executives and legislatures-has important implications for the study of international relations. A key implication is that some of what the law actually does takes place in the shadows. The mere threat of adjudication can prompt mobilization, bargains, and negotiations in ways that shape political decisions without any formal legal actions-a fact that has gone largely unnoticed by traditional international relations theory, which tends to focus on actual disputes and their settlements. This Thematic Section thus opens up a whole new range for the study of legal influence.

Moreover, the adjudication process itself, once it has kicked in, brings a range of new actors that have not traditionally been the focus of international relations theorists. Alongside states and their well-studied branches of government are many other actors, such as judges and arbitrators, that interject themselves into what traditionally have been considered state matters. Thus, for debates over compliance, looking simply to immediate state-driven outcomes may miss an essential element of law's influence. Legal scholars have long understood that law is a process; interjecting this insight into the study of international politics can-and should-change the way we study what legal institutions actually do and how they help or hinder different actors and actions.

Adjudication-and its very possibility-shapes legal discourse and state and international decision-making. More broadly, the "practice of legality" imparts a stability and a universality to international law that, at least in some circumstances, limits the extent to which the whims of executives are accepted within a single society or diffused around the world (Brunnée and Toope 2018). The constraints of this stability may be limited, as, for example, when President Trump follows prescribed legal steps to execute decisions to withdraw from international agreements or to levy tariffs, thereby avoiding litigation over alleged abuses of presidential authority (Nexon and Cooley, forthcoming). Yet, the "stickiness" of legal processes may also mean that, in the long run, Trump will fail to change the international institutions or laws he dislikes, avoiding a major disruption of the existing multilateral order. ${ }^{21}$

We do not dispute that power undergirds laws and legal practices, such as those concerning the use of force and the pursuit of vital national interests. ${ }^{22}$ But the interests

\footnotetext{
${ }^{21}$ Koh (2018) argues that transnational legal process leaves the laws and institutions in place, so that Trump is, in effect, "resigning without leaving" (chap. $3)$.

${ }^{22}$ A forthcoming special issue of Security Studies, "Hegemony Studies 3.0: The Dynamics of Hegemonic Orders," examines how hegemons shape and are constrained by the orders they construct and by the resistance these orders generate.
}

of great powers cannot explain all externally oriented national and international behaviors. It cannot explain why international laws do not maximally advantage hegemonic interests, why human rights advocacy has developed specific understandings of legal rights-claiming, why firms and bankers worry about and respond to legal regulations, or why national judges decide cases by applying settled principles of legal interpretation that ignore guidance from political actors.

This does not mean that state interests no longer matter; indeed, the more powerful a state is, the better it may be able to deflect legal processes or harness law as another tool in its arsenal (Kittrie 2016). But it does mean that state interests may be shaped, limited, and channeled by adjudicatory bodies and nonstate actors in ways not yet fully understood. This Thematic Section sets the stage for future research by theorizing the concept of judicialization as broader than adjudication by international courts and as beyond the control of executives and legislatures and by introducing some of the mechanisms and modalities by which judicialization can shift power away from states in ways that may-or may not-be reversible.

\section{References}

Abbott, Kenneth, Robert Keohane, Andrew Moravcsik, Anne-Marie SlaughTER, ANd Duncan Snidal. 2000. The Concept of Legalization. International Organization 54 (3): 401-20.

Ahmed, Azam. "Police Sex Abuse Case is Bad News for Mexico's Political Leader.” N.Y. Times, Accessed Sept. 28, 2018. https://www.nytimes. com/2016/09/23/world/americas/enrique-pena-nieto-commissionhuman-rights-investigate-rape.html.

Alford, Roger P. 2006. "Foreign Relations as a Matter of Interpretation: The Use and Abuse of Charming Betsy." Ohio State Law Journal 97 (6): 1339_ 90 .

Allee, Todd, And Manfred Elsig. 2016. "Why Do Some International Institutions Contain Strong Dispute Settlement Provisions? New Evidence from Preferential Trade Agreements." Review of International Organizations 11 (1): 89-120.

Allee, Todd, and Paul Huth. 2006. "Legitimizing Dispute Settlement: International Legal Rulings as Domestic Political Cover.” American Political Science Review 100 (2): 219-34.

Alter, Karen J. 2000. "The European Legal System and Domestic Policy: Spillover or Backlash.” International Organization 54 (3): 489-518.

. 2011. "The Evolving International Judiciary." Annual Review of Law and Social Science 7: 387-415.

- 2014. The New Terrain of International Law: Courts, Politics, Rights. Princeton: Princeton University Press.

. 2018a. "The Future of International Law." In The New Global Agenda, edited by Diana Ayton-Shenker, 25-42. Lanham, MA: Rowman \& Littlefield.

- 2018b. "National Perspectives on International Constitutional Review: Diverging Optics." In Comparative Judicial Review, edited by Erin Delaney and Rosalind Dixon, 244-71. United Kingdom: Edward Elgar Publishing.

. 2019. "Critical Junctures and the Future of International Courts in a Post-Liberal World Order." In The Future of International Courts and Tribunals: Regional, Institutional, and Procedural Challenges, edited by Avidan Kent, Nikos Skoutaris, and Jamie Trinidad. United Kingdom: Routledge.

Alter, Karen J., and Jeannette Vargas. 2000. "Explaining Variation in the Use of European Litigation Strategies: EC Law and UK Gender Equality Policy." Comparative Political Studies 33 (4): 316-46.

Alter, Karen J., and Laurence R. Helfer. 2010. "Nature or Nurture: Judicial Lawmaking in the European Court of Justice and the Andean Tribunal of Justice." International Organization 64 (4): 563-92.

Alter, Karen J., James T. Gathit, and Laurence R. Helfer. 2016. "Backlash Against International Courts in West, East, and Southern Africa: Causes and Consequences." European Journal of International Law 27 (2): 293-328. 
Alter, Karen J., Laurence R. Helfer, and Mikael Rask Madsen. 2018. International Court Authority. Oxford: Oxford University Press.

Apostolova, Ekaterina. 2010. "The Relationship Between the Alien Tort Statute and the Torture Victim Protection Act." Berkeley Journal of International Law 28 (2): 640-52.

Askin, Kelly Dawn. 2003. "Prosecuting Wartime Rape and Other GenderRelated Crimes Under International Law: Extraordinary Advances, Enduring Obstacles." Berkeley Journal of International Law 21 (2): 288-349.

BBC REPORT: Lithuania and Romania complicit in CIA torture - European court, BBC News. Accessed April 5, 2019, https://www.bbc.com/news/ world-europe-44313905.

BlankRome. Re-Imposing U.S. Sanctions on Iran: Key Issues for Global Business, International Trade. Accessed Sept. 20, 2018. https://www. blankrome.com/publications/re-imposing-us-sanctions-iran-keyissues-global-business.

Bookman, Pamela. 2015. "Litigation Isolationism." Stanford Law Review 67 (5): $1081-144$.

Börzel, Tanja. 2001. "Non-Compliance in the European Union: Pathology Or Statistical Artifact.” Journal of European Public Policy 8 (5): 803-24.

Brinks, Daniel M., ANd Abby Blass. 2017. "Rethinking Judicial Empowerment: The New Foundations of Constitutional Justice." International Journal of Constitutional Law 15 (2): 296-331.

Brunnée, Jutta, And Stephen J. Toope. 2017. "Interactional Legal Theory, the International Rule of Law, and Global Constitutionalism." In Handbook on Global Constitutionalism, edited by Anthony F. Lane and Antje Wiener. Edward Elgar.

- 2018. "International Law and the Practice of Legality: Stability and Change." Victoria University of Wellington Law Review 49 (4): 170-82.

Burley, Anne-Marie, and Walter Mattli. 1993. "Europe Before the Court." International Organization 47 (1): 41-76.

Busch, Marc L. 2007. "Overlapping Institutions, Forum Shopping, and Dispute Settlement in International Trade." International Organization 61 (4): 735-61.

Busch, Marc L, and Eric Reinhardt. 2000a. "Bargaining in the Shadow of the Law: Early Settlement in GATT/WTO Disputes." Fordham International Law Journal 24 (November-December): 148-72.

- 2000b. "Testing International Trade Law: Empirical Studies of GATT/WTO Dispute Settlement.” In The Political Economy of International Trade Law: Essays in Honor of Robert Hudec, edited by Daniel L.M. Kennedy and James D. Southwick, 457-81. Cambridge: Cambridge University Press.

— 2006. "Three's a Crowd: Third Parties and WTO Dispute Settlement." World Politics 58 (3): 446-77.

Büthe, Tim, and Helen V. Milner. 2014. "Foreign Direct Investment and Institutional Diversity in Trade Agreements: Credibility, Commitment, and Economic Flows in the Developing World, 1971-2007." World Politics 66 (1): 88-122.

Büthe, Tim, and Walter Mattui. 2011. The New Global Rulers: The Privatization of Regulation in the World Economy. Princeton, NJ: Princeton University Press.

Butler-Stroud "Japan Finally Accepts ICJ Ruling Applies to All Scientific Whaling" Whale and Dolphin Conservation. Accessed April 5, 2019. http://us.whales.org/blog/2016/04/japan-finally-accepts-icjruling-applies-to-all-scientific-whaling.

Chayes, Abram. 1974. The Cuban Missile Crisis: International Crises and the Role of Law. New York: Oxford University Press.

CheCKeL, JefFrey. 1999. "Why Comply? Constructivism, Social Norms, and the Study of International Institutions." Arena Working Paper WP 99/24.

Chiara, Giorgetti. 2017. "International Adjudicative Bodies." In The Oxford Handbook on International Organizations, edited by Jacob Katz Cogan, Ian Hurd, and Ian Johnstone. Oxford: Oxford University Press.

Cloward, Karisa. 2014. "False Commitments: Local Misrepresentation and the International Norms against Female Genital Mutilation and Early Marriage." International Organization 68 (3): 495-526.

Conen, Jerome A. "The Belt and Road Initiative (BRI) Courts? China's Attitude Towards Dispute Resolution”, Jerry's Blog. Accessed Sept. 282018. http://www.jeromecohen.net/jerrys-blog/the-bri-courts.

Contesse, Jorge. The Inter-American Court of Human Rights' Advisory Opinion on Gender Identity and Same-Sex Marriage, ASIL Insights, vol. 22, issue 9. Accessed July 26, 2018. https://www.asil.org/ insights/volume/22/issue/9/inter-american-court-human-rightsadvisory-opinion-gender-identity-and.

Council of the European Union Press Release. "Multilateral Investment court: Council Gives Mandate to the Commission to Open Negotia- tion." Accessed March 20, 2018, http://www.consilium.europa.eu/en/ press/press-releases/2018/03/20/multilateral-investment-courtcouncil-gives-mandate-to-the-commission-to-open-negotiations/.

Court of Justice of the European Community Judgment in Case C- 216/18 PPU, Minister for Justice and Equality v LM (Deficiencies in the system of justice) of July 25, 2018; European Commission, Press Release, Rule of Law: Commission launches infringement procedure to protect the independence of the Polish Supreme Court. Accessed July 2, 2018. http://europa.eu/rapid/press-release_IP-18-4341_en.htm.

Davenport, Kelsey. "EU Acts to Block US Sanctions on Iran" Arms Control Today. Accessed Sept. 20, 2018. https://www.armscontrol.org/ act/2018-07/news/eu-acts-block-us-sanctions-iran.

Davis, Christina L. 2012. Why Adjudicate?: Enforcing Trade Rules in the WTO. Princeton, NJ; Oxford: Princeton University Press.

Davis, Christina L., and Sarah Blodgett Bermeo. 2009. "Who Files? Developing Country Participation in WTO Adjudication." Journal of Politics 71 (3): 1033-49.

de la Rasilla, Ignacio, and Jorge E. Viñuales. 2019. Experiments in International Adjudication: Historical Accounts. Cambridge: Cambridge University Press.

Dür, Andreas, And Manfred Elsig. 2015. Trade Cooperation: The Purpose, Design, and Effects of Preferential Trade Agreement World Trade Forum. Cambridge: Cambridge University Press.

Dyzenhaus, David. 2012. "Constitutionalism in an Old Key: Legality and Constituent Power." Global Constitutionalism 1 (2): 229-60.

Epps, Charles. 1998. The Rights Revolution: Lawyers, Activists, and Supreme Courts in Comparative Perspective. Chicago: University of Chicago Press.

Ferejohn, John. 2002. "Judicializing Politics, Politicizing Law." Law and Contemporary Problems 65 (3): 41-68.

FinNemore, Martha. 1999. "Are Legal Norms Distinct?" Journal of International Law and Politics 32 (3): 699-706.

Fortes, Pedro, Larissa Verri Boratti, Andrés Palacios Lleras, and Tom Gerald DaLy. 2017. Law and Policy in Latin America: Transforming Courts, Institutions, and Rights. London: Palgrave Macmillan.

Galanter, Marc. 1974. "Why the 'Haves' Come Out Ahead: Speculations on the Limits of Legal Change." Law and Society Review 9 (1): 95.

Garrett, Geoffrey, and Barry Weingast. 1993. "Ideas, Interests, and Institutions: Constructing the EC's Internal Market." In Ideas and Foreign Pol$i c y$, edited by Judith Goldstein and Robert Keohane, 173-206. Ithaca, NY: Cornell University Press.

Ginsburg, Tom. 2008. "The Global Spread of Constitutional Review." In The Oxford Handbook on Law and Politics, edited by Keith Whittington, Daniel Keleman, and Gregory A. Caldeira, 81-98. Oxford: Oxford University Press.

Ginsburg, Tom, and Daniel Abebe. 2019. The Dejudicialization of International Politics? International Studies Quarterly 63 (3): 521-30.

Goldsmith, Jack, and Daryl Levinson. 2009. "Law for States: International Law, Constitutional Law, Public Law." Harvard Law Review 122 (7): 1792-868.

Goldstein, Judith, Miles Kahler, Robert Keohane, and Anne-Marie Slaughter. 2000. "Introduction: Legalization and World Politics." International Organization 54 (3): 385-400.

Goodman, Ryan, and Derek Jinks. 2013. Socializing States: Promoting Human Rights through International Law. Oxford: Oxford University Press.

Goodman, Ryan, Derek Jinks, And Andrew K. Woods, eds. 2012. Understanding Social Action, Promoting Human Rights. Oxford: Oxford University Press.

Graham, Euan. The Hague Tribunal's South China Sea Ruling: Empty Provocation or Slow-Burning Influence? Council of Councils Global Memo. Accessed Aug 18, 2016. https://www.cfr.org/councilofcouncils/ global_memos/p38227.

Greenhouse, Linda, and Reva B. Siegel. 2011. "Before (and After) Roe v. Wade: New Questions About Backlash.” Yale Law Journal 120 (8): 203087.

Hafner-Burton, Emile M. 2005a. "Trading Human Rights: How Preferential Trade Agreements Influence Government Repression." International Organization 59 (3): 593-629.

- 2005b. "Forum Shopping for Human Rights: The Transformation of Preferential Trade." Paper presented at the American Political Science Association Conference, September 1-4, 2004, Washington, DC. - 2012. "International Human Rights Regimes." Annual Review of Political Science 15: 265-86.

. 2013. Making Human Rights a Reality. Princeton: Princeton University Press. 
Hafner-Burton, Emile M., and Kiyoteru Tsutsui. 2004. "Justice Lost! The Failure of International Human Rights Law to Matter Where Needed Most." Journal of Peace Research 44 (4): 407-25.

- 2005. "Human Rights Practices in a Globalizing World: The Paradox of Empty Promises." American Journal of Sociology 110 (5): 1373-411.

Hafner-Burton, Emilie M., David G. Victor, and Brad L. Leveck. 2016. "How Activists Perceive the Utility of International Law." Journal of Politics 78 (1): $167-80$.

Hafner-Burton, Emile M., Sergio Puig, and David G. Victor. 2017. "Against Secrecy: The Social Cost of Secrecy in International Adjudication." Yale Journal of International Law 42 (2): 279-343.

Hafner-Burton, Emilie M., Stephan Haggard, David A. Lake, and David G. VicTOR. 2017. "The Behavioral Revolution and International Relations." International Organization 71 (S1): S1-S31.

Hafner-Burton, Emilie M., Zachary C. Steinert-Threlkeld, and David G. VicTOR. 2016. "Predictability Versus Flexibility: Secrecy in International Investment Arbitration." World Politics 68 (3): 413-53.

Halliday, Terence C., and Gregory Shaffer. 2015. Transnational Legal Orders / Edited By. Cambridge: Cambridge University Press.

Halliday, Terence C., Lucien Karpik, and Malcolm Feeley. 2007. Fighting for Political Freedom: Comparative Studies of the Legal Complex and Political Liberalism, Oñati International Series in Law and Society. Oxford; Portland, OR: Hart.

Harlow, Carol, and Richard Rawlings. 1992. Pressure through Law. London: Routledge.

Hathaway, Oona, and Scott J. Shapiro. 2011. "Outcasting: Enforcement in Domestic and International Law." Yale Law Journal 121 (2): 252.

Hawkins, Darren, and Wade Jacoby. 2010. "Partial Compliance: A Comparison of the European and Inter-American Court of Human Rights." Journal of International Law and International Relations 6 (1): 35-85.

Helfer, Laurence R. 1999. "Forum Shopping for Human Rights." University of Pennsylvania Law Review 148 (2): 285-399.

- 2002. "Overlegalizing Human Rights: International Relations Theory and the Commonwealth Caribbean Backlash Against Human Rights Regimes." Columbia Law Review 102 (7): 1832-911.

. 2006. "Why State Create International Tribunals: A Theory of Constrained Independence." In International Conflict Resolution, edited by Stefan Voigt, Max Albert and Dieter Schmidtchen. Tübigen, Germany: Mohr Seibeck.

Helfer, Laurence R., And Anne E. Showalter. 2017. "Opposing International Justice: Kenya's Integrated Backlash Strategy against the ICC.” International Criminal Law Review 17 (1): 1-46.

Helfer, Laurence R., and Anne-Marie Slaughter. 2005. "Why States Create International Tribunals: A Response to Professors Posner and Yoo." California Law Review 93 (May): 899-956.

Helfer, Laurence R., and Erik Voeten. 2014. "International Courts as Agents of Legal Change: Evidence from LGBT Rights in Europe." International Organization 68 (1): 77-110.

Hillman, Jonathan, and Mathew P. Goodman "China's Belt and Road Court to Challenge the Current US-Led Order" in The Financial Times. Accessed Sept. 28 2018. https://www.ft.com/content/b64d7f2e-8f4d-11e8-b6397680 cedcc 421

HiRschl, RAn. 2004. Towards Juristocracy: The Origins and Consequences of the New Constitutionalism. Cambridge: Harvard University Press.

- 2008. "The Judicialization of Mega-Politics and the Rise of Political Courts." Annual Review of Political Science 11 (1): 93-118.

- 2014. Comparative Matters: The Renaissance of Comparative Constitutional Law / Ran Hirschl. 1st ed. Oxford: Oxford University Press.

Hooghe, Liesbet, Gary Marks, Arjan H. Schakel, Sandra Chapman Osterkatz, Sara Niedzwiecki, and Sarah Shair-Rosenfield. 2016. Measuring Regional Authority: A Postfunctionalist Theory of Governance. Oxford: Oxford University Press.

Hoven, Elisa, and Saskia Scheibel. 2015. "Justice for Victims in Trials of Mass Crimes." International Review of Victimology 21 (2): 161-85.

Howse, Robert, and Rudi Teitel. 2010. "Beyond Compliance: Rethinking Why International Law Really Matters." Global Policy 1 (2): 127-35.

Hudec, Robert E. 1971. "GATT Or GABB: The Future Design of the General Agreement on Tariffs and Trade." Yale Law Journal 80 (7): 1299-386.

Hull, Isabel V. 2014. A Scrap of Paper: Breaking and Making International Law During the Great War. Ithaca, NY: Cornell University Press.

Huneeus, Alexandra. 2013. "International Criminal Law by Other Means: The Quasi-Criminal Jurisdiction of Human Rights Courts." American Journal of International Law 107 (1): 1-44.

- 2018. "Legitimacy and Jurisdictional Overlap." In Legitimacy and International Courts, edited by Nienke Grossman, Harlan Grant Cohen,
Andreas Follesdahl, and Geir Ulfstein, 114-42. Cambridge: Cambridge University Press.

Huneeus, Alexandra, Javier A. Couso, and Rachel Sieder. 2011. Cultures of Legality: Judicialization and Political Activism in Latin America. Cambridge: Cambridge University Press.

Huth, Paul, and Todd Allee. 2006. "The Pursuit of Legal Settlements to Territorial Disputes." Conflict Management and Peace Science 23 (4): 285-308.

Kahler, Miles. 2000. "Legalization as a Strategy: The Asian Pacific Case." International Organization 54 (3): 549-71.

Katzenstein, Suzanne. 2014. "In the Shadow of Crisis: The Creation of International Courts in the Twentieth Century." Harvard Journal of International Law 55 (1): 151-209.

Keohane, Robert. 1997. "International Relations and International Law: Two Optics." Harvard Journal of International Law 38 (Spring): 487-502.

Keohane, Robert, Andrew Moravcsik, and Anne-Marie Slaughter. 2000. "Legalized Dispute Resolution: Interstate and Transnational." International Organization 54 (3): 457-88.

Kingsbury, Benedict. 2011. "International Courts: Uneven Judicialization." In Cambridge Companion to International Law, edited by James Crawford and Martin Koskenniemi. Cambridge: Cambridge University Press.

Kirby, Michael. 2001. "Law and Sexuality: The Contrasting Case of Australia." Stanford Law \& Policy Review 12 (1): 103-16.

KitTRIe, ORde F. 2016. Lawfare: Law as a Weapon of War. Oxford: Oxford University Press.

KoH, Harold Hongu. 2018. The Trump Administration and International Law. Oxford: Oxford University Press.

Koremenos, Barbara. 2008. "When, What, and Why Do States Choose to Delegate?" Law and Contemporary Problems 71 (1): 151-91.

Koremenos, Barbara, and Timm Betz. 2013. "The Design of Dispute Settlement Procedures in International Agreements." In Interdisciplinary Perspectives on International Law and International Relations: The State of the Art, edited by Jeffrey Dunoff and Mark Pollack, 371-93. New York: Cambridge University Press.

Larsson, Olof, and Daniel Naurin. 2016. "Judicial Independence and Political Uncertainty: How the Risk of Override Affects the Court of Justice of the Eu." International Organization 7 (2): 377-408.

Larsson, Olof, and Daniel Naurin. 2019. Split Vision. Multidimensionality in the European Union's Legal Policy Space. International Studies Quarterly 63 (3): 492-506.

Linos, Katerina, and Tom Pegram. 2016. "Architects of Their Own Making: National Human Rights Institutions and the United Nations." Human Rights Quarterly 38 (4): 1109-34.

2017. "What Works in Human Rights Institutions." American Journal of International Law 111 (3): 628-88.

Lupu, Yonatan, Pierre-Hugues Verdier, and Mila Versteeg. 2019. The Strength of Weak Review: National Courts, Interpretive Canons, and Human Rights Treaties. International Studies Quarterly 63 (3): 507-20.

Madsen, Mikael Rask, Pola Cebulak, and Micha Wiebush. 2018. "Backlash Against International Courts: Explaining the Forms and Patterns of Resistance to International Courts." International Journal of Law in Context 14 (2): 197-220.

Martin, Lisa. 2013. "Against Compliance." In Interdisciplinary Perspectives on International Law and International Relations: The State of the Art, edited by Jeffrey Dunoff and Mark Pollack, 591-612. New York: Cambridge University Press.

McCall Smith, James. 2000. "The Politics of Dispute Settlement Design." International Organization 54 (1): 137-80.

Mnookin, Robert, ANd Louis Kornhauser. 1979. "Bargaining in the Shadow of the Law: The Case of Divorce." Yale Law Journal 88 (5): 950-97.

Moorehead, Alex, and Alex Whiting. Countries' Reactions to Bolton's Attack on the ICC, Just Security Blog. Accessed Sept. 18, 2018. https://www. justsecurity.org/60773/countries-reactions-boltons-attack-icc/.

MoraVCSIK, ANDREw. 1995. "Explaining International Human Rights Regimes: Liberal Theory and Western Europe." European Journal of International Relations 1 (2): 157-89.

. 2000. "The Origins of Human Rights Regimes: Democratic Delegation in Postwar Europe." International Organization 54 (2): 217-52.

NePhew, Richard. "In Exiting the Iran Deal, Trump Left the UN Sanctions Relief Intact-why That Could Pose Problems Down the Road" Brookings. Accessed Sept. 20, 2018. https://www.brookings.edu/blog/orderfrom-chaos/2018/05/17/in-exiting-the-iran-deal-trump-left-u-nsanctions-relief-intact-why-that-could-pose-problems-down-the-road/ .

Nexon, Daniel H., and Alex Cooley. Forthcoming. Pathways out of Hegemony: How the American International Order Might Unravel. Oxford: Oxford University Press. 
O'Connell, Mary Ellen, and Lenore VanderZee. 2014. "The History of International Adjudication." In Oxford Handbook on International Adjudication, edited by Cesare Romano, Karen J. Alter, and Yuval Shany, 40-62. Oxford: Oxford University Press.

Paumelyn, Joost, and Luiz Eduard Salles. 2009. "Forum Shopping Before International Tribunals: (Real) Concerns, (Im)Possible Solutions." Cornell International Law Journal 42 (1): 77-117.

Paumelyn, Joost, and Manfried Elsig. 2012. "The Politics of Treaty Interpretation: Variations and Explanations Across International Tribunals." In Interdisciplinary Perspectives on International Law and International Relations: The State of the Art, edited by Jeffrey Dunoff and Mark Pollack, 445-75. New York: Cambridge University Press.

Peinhardt, Clint, and Rachel L. Wellhausen. 2016. "Withdrawing from Investment Treaties But Protecting Investment." Global Policy 7 (4): 57176.

Pelc, Krzysztof J. 2014. "The Politics of Precedent in International Law: A Social Network Application." American Political Science Review 108 (2): $547-64$.

Pelc, Krzyzstof, and Mark Busch. 2019. Words Matter: How Wto Rulings Handle Controversy. International Studies Quarterly 63 (3): 464-76.

Putnam, Tonya L. 2016. Courts without Borders: Law, Politics, and US Extraterritoriality. Cambridge: Cambridge University Press.

Raustiala, Kal. 2009. Does the Constitution Follow the Flag: The Evolution of Territoriality in American Law. Oxford: Oxford University Press.

Reinhardt, Eric. 1999. "Aggressive Multilateralism: The Determinants of GATT/WTO Dispute Initiation, 1948-1998." Accessed April 5, 2019. http://www.isr.umich.edu/cps/pewpa/archive/archive_99/ 19990004.pdf.

—. 2001. "Adjudication Without Enforcement in GATT Disputes." Journal of Conflict Resolution 45 (2): 174-95.

Risse, Thomas, Stephen Ropp, and Kathryn Sikkink. 1999. The Power of Human Rights: International Norms and Domestic Change. Cambridge: Cambridge University Press.

— 2013. Persistent Power of Human Rights. Cambridge: Cambridge University Press.

Roberts, Anthea. 2018. "Incremental, Systemic, and Paradigmatic Reform of Investor-State Arbitration." American Journal of International Law 112 (3): 410-32.

Rogers, Catherine A. 2013. "The Politics of International Investment Arbitrators." Santa Clara Journal of International Law 12 (1): 223-62.

Roht-Arriaza, Naomi. 2005. The Pinochet Effect: Transnational Justice in the Age of Human Rights, Pennsylvania Studies in Human Rights. Philadelphia: University of Pennsylvania Press.

Romano, Cesare. 1999. "The Proliferation of International Judicial Bodies: The Pieces of the Puzzle." New York University Journal of International Law and Politics 31 (Summer): 709-51.

- 2007. "The Shift from the Consensual to the Compulsory Paradigm in International Adjudication: Elements for a Theory of Consent." New York University Journal of International Law and Politics 39 (4): 791872 .

- 2011. "A Taxonomy of International Rule of Law Institutions." Journal of International Dispute Settlement 2 (1): 241-77.

- 2014a. "The Shadow Zones of International Judicialization." In $O x$ ford Handbook on International Adjudication, edited by Cesare Romano, Karen J. Alter, and Yuval Shany, 90-110. Oxford: Oxford University Press.

- 2014b. "Trial and Error in International Judicialization." In $O x$ ford Handbook on International Adjudication, edited by Cesare Romano, Karen J. Alter, and Yuval Shany, 111-34. Oxford: Oxford University Press.

. 2019. "Mirage in the Desert: Regional Judicialization in the Arab World." In Experiments in International Adjudication: Historical Accounts, edited by Ignacio de la Rasilla and Jorge E. Viñuales. Cambridge: Cambridge University Press.

Romano, Cesare, Karen J. Alter, and Yuval Shany. 2014. "Mapping International Courts and Tribunals, the Issues and Players." In Oxford Handbook on International Adjudication, edited by Cesare Romano, Karen J. Alter and Yuval Shany, 3-26. Oxford: Oxford University Press.

Rosenberg, Gerald N. 1993. The Hollow Hope: Can Courts Bring About Social Change? American Politics and Political Economy Series. Chicago: University of Chicago.

Samp, Rich. U.S. Supreme Court Continues to Nibble Away at Alien Tort Statute's Sweep, Forbes. Accessed Sept. 27, 2018. https://www.forbes.com/ sites/wlf/2018/04/25/u-s-supreme-court-continues-to-nibble-away-atalien-tort-statutes-sweep/\#5ab7ca6ad9fe
Scheppele, Kim. 2017. "Worst Practices and the Transnational Legal Order or How to Build a Constitutional 'Democratorship' in Plain Sight." Available at https://www.law.utoronto.ca/utfl_file/count/ documents/events/wrightscheppele2016.pdf.

Shaffer, Gregory C. 2003. Defending Interests: Public-Private Partnerships in WTO Litigation. Washington, DC: Brookings.

Shaffer, Greg C., Manfred Elsig, and M. A. Pollack. 2017. "Us Threats to the WTO Appellate Body." Available at SSRN: https://ssrn. com/abstract $=3087524$.

Shaffer, Gregory C., Michell Ratton Sanchez Badin, and Barbara Rosenberg. 2008. "The Trials of Winning at the WTO: What Lies Behind Brazil's Success." Cornell International Law Journal 41 (2): 383-502.

Sieder, Rachel, Line Schjolden, and Alan Angell. 2005. The Judicialization of Politics in Latin America, Studies of the Americas. New York; Basingstoke: Palgrave Macmillan.

- 2005. "The Transnational Dimension of the Judicialization of Politics in Latin America." In The Judicialization of Politics in Latin America, edited by Rachel Sieder, Line Schjolden, and Alan Angell, 263-92. New York: Palgrave MacMillan.

Sikкink, Kathrin. 2011. The Justice Cascade: How Human Rights Prosecutions Are Changing World Politics. New York: Norton.

Simmons, Beth. 2002. "Capacity, Commitment, and Compliance: International Institutions and Territorial Disputes." Journal of Conflict Resolution 46 (6): 829-56.

- 2005. "Rules over Real Estate: Trade, Territorial Conflict, and International Borders As Institution." Journal of Conflict Resolution 49 (6): $823-48$.

- 2006. "Trade and Territorial Conflict in Latin America: International Borders as Institutions." In Territoriality and Conflict in an Era of Globalization, edited by Miles Kahler and Barbara Walter, 251-87. Cambridge: Cambridge University Press.

Sirleaf, Matiangai. 2017. "The African Justice Cascade and the Malabo Protocol." International Journal of Transitional Justice 11 (1): 71-91.

Staton, Jeffrey, and William Moore. 2011. "The Last Pillar to Fall? Judicial Power in Domestic and International Politics." International Organization 65 (3): 553-88.

Staton, Jeffrey, and Angela Romero. 2019. Rational Remedies: The Role of Opinion Clarity in the Inter-American Human Rights System. International Studies Quarterly 63 (3): 477-91.

Steinberg, Richard H. 2002. "In the Shadow of Law or Power? ConsensusBased Bargaining and Outcomes in the GATT/WTO." International Organization 56 (2): 339-74.

Stone Sweet, Alec. 1992a. The Birth of Judicial Politics in France: The Constitutional Council in Comparative Perspective. New York: Oxford University Press.

. 1992b. "Where Judicial Politics Are Legislative Politics: The French Constitutional Council." Western European Politics 15 (3): 29-49. . 2000. Governing with Judges. Oxford: Oxford University Press.

Stone Sweet, Alec, and Thomas Brunell. 2012. "The European Court of Justice, State Non-Compliance, and the Politics of Override: Reply to Carrubba, Gabel, and Hankla." American Political Science Review 106 (1): 204-13.

Streeck, Wolfgang, and Kathleen Ann Thelen. 2005. Beyond Continuity: Institutional Change in Advanced Political Economies. Oxford; New York: Oxford University Press.

Suri, MANIL. "India's Riotous Triumph of Equality", NY Times. Accessed Sept. 27, 2018. https://www.nytimes.com/2018/09/07/opinion/ sunday/india-supreme-court-gay-rights.html.

SzewCZyK, Bart M.J. 2014. "Customary International Law and Statutory Interpretation: An Empirical Analysis of Federal Court Decisions." George Washington Law Review 82 (4): 1118-92.

Tate, C. Neal. 1995. "Why the Expansion of Judicial Power." In The Global Expansion of Judicial Power, edited by C. Neal Tate and Torbjörn Vallinder, 27-36. New York: New York University Press.

Tate, C. Neal, and Torbjörn Vallinder. 1995. The Global Expansion of Judicial Power. New York: New York University Press.

Tignino, Mara. 2016. "Quasi-Judicial Bodies." In Research Handbook on the Theory and Practice of International Law-Making, edited by Catherine Bröllman and Yannick Radi, 242-61. Northhampton, MA: Edward Elgar.

Thapa, Saurav Jung. "Marriage Equality on the Horizon in Costa Rica", Human Rights Campaign. Accessed Nov. 16, 2018. https://www. hrc.org/blog/marriage-equality-on-the-horizon-in-costa-rica-possiblya-first-in-cen.

Worstall, Tim. GOP And Trump Beware - EU Planning WTO Case Against Border Adjustment Tax, Forbes. Accessed Sept. 27, 2018. 
https://www.forbes.com/forbes/welcome/?toURL=https://www. forbes.com/sites/timworstall/2017/02/14/gop-and-trump-bewareeu-planning-wto-case-against-border-adjustment-tax $/$ \&refURL= https://www.google.com/\&referrer=https://www.google.com/.

Thrush, Glenn. "Trump Opens New Front in His Battle With China: International Shipping." N.Y. Times. Accessed October 18, 2018. https://www.nytimes.com/2018/10/17/us/politics/trump-chinashipping.html.

van Alebeek, Rosanne, and André Nollkaemper. 2012. "The Legal Status of Decisions by Human Rights Treaty Bodies in National Law." In UN Human Rights Treaty Bodies: Law and Legitimacy, edited by Helen Keller, Geir Ulfstein, and Leena Grover, 356-413. Cambridge: Cambridge University Press. van den Berg, Stephanie, and Tony Sterling "World Court Hears Iran Lawsuit to Have US Sanctions Lifted” Reuters. Accessed Sept. 20, 2018. https://www.reuters.com/article/us-iran-nuclear-usa-sanctions/ world-court-hears-iran-lawsuit-to-have-us-sanctions-liftedidUSKCN1LC00G.

Verdier, Pierre-Hugues, and Erik Voeten. 2015. "How Does Customary International Law Change?" Case of State Immunity. (Report) 59 (2): 209.

Verdier, Pierre-Hugues, and Mila Versteeg. 2015. "International Law in National Legal Systems: An Empirical Investigation." American Journal of International Law 109 (3): 514-33.

Weiler, Joseph. 1991. "The Transformation of Europe.” Yale Law Journal 100 (8): 2403-83. 